\title{
Use of insect products in pig diets
}

\author{
T. Veldkamp" and A.G. Vernooij \\ Wageningen Livestock Research, De Elst 1,6700 AH Wageningen, the Netherlands; teun.veldkamp@wur.nl
}

Received: 30 July 2020 / Accepted: 15 October 2020

() 2021 Wageningen Academic Publishers

OPEN ACCESS C(1)@() REVIEW ARTICLE

\begin{abstract}
This review is focusing on effects of inclusion of insect products in pig diets on digestibility, performance, product quality, and health parameters. In 2019 pig feed accounts for 23\% of the global feed production. Soybean meal is the most common protein source in pig diets. A shift towards more sustainable feed ingredients can improve the sustainability of entire pig production. Novel protein sources currently evaluated in diets for piglets and growing pigs are insect-based ingredients. Insects are able to convert organic biomass into high-quality protein. Currently the use of insects as protein source in pig diets is not allowed due to transmissible spongiform encephalopathies regulation but it is expected that this will be allowed in the near future. Research efforts on effects of inclusion of insect products on nutrient digestibility, growth performance, product quality and pig health are therefore increasing. Nutrient digestibility of evaluated insect proteins was comparable with traditional protein sources. Nutrient digestibility of insect-based diets as well as effects on growth performance in pigs fed insect-based diets differed between studies. The differences in responses are mainly due to changes in diet ingredients and nutrient composition when insect products are included. Health related parameters were not affected by dietary inclusion of insect products. In general it can be stated that differences in results between studies may be due to different insect species and life stages being used, differences in nutritional value of the insect products, in dietary inclusion levels, in processing techniques applied, effects on palatability of the diet, (weaning) age of the animals involved and research methods applied. Overall, insect products seem to be a good alternative to partly replace traditional protein-rich ingredients in pig diets without adversely affecting growth performance, product quality and health, but more standardised research is required to reduce differences between studies.
\end{abstract}

Keywords: insect protein, feed, pigs, digestibility and growth performance, animal health

\section{Introduction}

This review is focusing on effects of inclusion of insect products in pig diets on nutrient digestibility of the diet, animal performance, product quality, and health parameters. The review starts with a general description of the development of pig production in the past and expected developments in the future as well as sustainability aspects in pig production mainly focussing on pig nutrition and possibilities on how to create more sustainable pig diets by use of insect-based feed ingredients. The chemical compositions of different insect species are presented and compared to the chemical composition of traditional protein sources such as soybean meal and fishmeal. The chemical composition of insect protein is important to put the effect of nutrient digestibility of insect proteins on the overall nutritional value in perspective. Only relevant papers for evaluation of nutrient digestibility, growth performance, product quality, and health parameters, published since 2000 , were considered. For studies on effects of inclusion of insect products as feed ingredient in pig diets on growth performance only papers were included which met the criteria of isonitrogenously and isocalorically formulated diets. This was done to ensure that outcome parameters can be solely attributed to the inclusion of insect-based feed ingredients in the diet and not to differences in protein levels or energy levels. 


\section{Global meat consumption and pig production}

In the past 50 years, global pig production has quadrupled and is expected to continue to grow in the next three decades. This may have a significant impact on feed use and land demand (Lassaletta et al., 2019). The growing demand for pig meat results from the increase in population, as well as from the transition of the diet towards more animal protein consumption per capita (Bai et al., 2018; Lassaletta et al., 2014). Globally, meat consumption is generally influenced by a number of factors, such as food consumption patterns, the standard of living, meat production and animal husbandry conditions and product pricing. Also many consumers will change their eating habits, including consumption of more animal protein when urbanisation intensifies (Soare and Chiurciu, 2017). Although in Western Europe the consumption of meat is not expected to increase much (De Boer et al., 2006), it has been forecasted that the worldwide demand for animal products will grow significantly in the coming decades, and that the global production of meat will double in 2050 taking 1999 as the base year (Steinfeld et al., 2006). Globally, 767.5 billion pigs were produced in 2019 (USDA, 2020). Global feed production is estimated at 1,126 million metric tons in 2019 (Alltech, 2020). The production of pig feed in 2019 is estimated to be 261 million metric tons, accounting for $23.2 \%$ of the total global feed production. In 2019, pig feed production in Europe was 79.5 million metric tons, accounting for $30 \%$ of the total pig feed production (Alltech, 2020). The expected increase of global population and consumption of pig meat will require a higher demand for pig feed in the future.

\section{Sustainability aspects of pig diets}

Meat consumption contributes to the supply of energy, protein, essential amino acids and important micronutrients (e.g. long-chain n-3 fatty acids, copper, iron, iodine, manganese, selenium, zinc, B-vitamins) in the human food chain (De Smet and Vossen, 2016). However, despite the benefits of meat consumption, the increase in the number of livestock directly challenges the sustainability of animal production because it profoundly impacts our planet. The General Assembly of the United Nations has defined the goals of sustainable agriculture to ensure economic viability, protect natural resources, provide ecosystem services, manage rural areas, improve the quality of life in agricultural areas, ensure animal welfare and produce safe and healthy food (UN, 2015). The EU goals for animal production are in particular to increase the competitiveness and economic viability of animal production systems, to improve livestock's adaptation to diseases and increasingly extreme weather patterns related to climate change, to address issues related to diet and health, ammonia and air quality, and issues related to greenhouse gas emissions and climate change, nitrate emissions and degradation of natural resources such as water, soil and biodiversity, global food security, global trade and animal welfare (ERANET, 2020). The negative impact of livestock production on our earth can be reduced by two alternative scenario's for improving the sustainability of future pig production systems (Rauw et al., 2020). The first scenario is a high input-high output system based on sustainable intensification, maximising animal protein production efficiency on a limited land surface at the same time as minimising environmental impacts. The second scenario is a reduced input-reduced output system based on selecting animals that are more robust to climate change and are better adapted to transform low quality feed (local feeds, feedstuff co-products, food waste) into meat. Sustainability can be increased with a shift from dependence on optimally formulated feed based on imported feed ingredients and use of feed grains to use of feeds based on locally produced ingredients and co-products not fit for use as human food (Mottet et al., 2017). Soybean meal has a relatively high protein content (45-50\%) with an adequate amino acid profile, low variation in nutrient composition, and contains anti-nutritional factors that are easily reduced by heat processing and is therefore a suitable ingredient in pig diets. It is an important source of the amino acid lysine, which is the first limiting amino acid in diets for pigs (De Visser et al., 2014), and other essential amino acids. Therefore, more than $50 \%$ of the total dry matter (DM) intake of pigs is based on cereals, while $9-25 \%$ is covered by oil meals, including soybean meal. In the European Union, soybean meal is the major oil seed meal consumed in animal nutrition and a large percentage of the used soybean is imported, because European production of soybean is low, compared to other oil seeds (Florou-Paneri et al., 2014). The inclusion of other oilseed meals to reduce dependence on imported soybean meal, such as sunflower meal or rapeseed meal in pig diets can provide opportunities to diversify the feed matrix by using home-grown feed ingredients. These alternative feed ingredients can partially or completely replace soybean meal in pig feed, especially during growing and finishing periods. There are other protein sources that can be used for pig nutrition, such as cottonseed meal, flaxseed meal, peas and faba beans. A potential alternative protein source for animal and pig feed are also insects and insects derived products which have a lower environmental footprint related to lower land use, water use and less emissions (Van Huis and Oonincx, 2017).

\section{Pig production systems and pig nutrition}

Specialised pig farms generally have a large number of animals. In specialised pig farming, three types of business can be created, such as breeding farms, finishing farms, farrowing to finisher farms, and there are also farms that keep pigs as an auxiliary activity (Anonymous, 2017). Breeding farms are involved in piglet production. Sow milk is the most important source of nutrients for piglets. Milk 
also contains protective substances (e.g. immunoglobulins) against multiple pathogens. At weaning at about four weeks of age, piglets have to change from fluid to solid feed. This requires adjustments of the digestive system and further development of the immune system. Generally highly digestible ingredients and protein sources are used in piglets in the post-weaning phase (whey, soybean derived protein sources, cooked cereals and fish meal). Weaning also include transfer of piglets to a new environment. This transition to a change in feed is often accompanied by a decrease in feed intake (FI) and a risk for infection by pathogenic Escherichia coli and streptococci inducing health disorders. Piglets are transferred to a finishing pig farm when they weigh around $25 \mathrm{~kg}$ (age about 10 weeks). The finishing pig farm is dedicated to raise piglets to finishing pigs. The pigs stay here until they weigh about 120 $\mathrm{kg}$ (age about 6 months). The pigs are then slaughtered and processed into pig meat for consumption by consumers. The dietary protein and essential amino acid requirements decrease as pigs grow older. To maximise piglet growth, it is recommended that levels of crude protein (CP) be at $20-23 \%$ in pre-starter and $18-20 \%$ in starter diets. Recommended levels of crude protein in finisher diets decrease from about $19 \%$ at 10 weeks of age to $13 \%$ in the pre-slaughter phase. Most common feed ingredients used in finisher diets are cereals such as corn and wheat and the remainder mainly consists of soybean meal, sunflower seed meal, wheat middlings and palm kernel meal. Use of soybean meal, the major protein source included in pig diets, has a large environmental impact due to land and water use to grow soybeans and the large-scale and -distance transportation of this ingredient (Wiedemann et al., 2016). Replacement of soybean meal with locally derived vegetal protein sources will reduce requirements for transport but land use will not reduce. By use of insects as feed ingredient associated transport and land use will reduce (Van Zanten et al., 2018).

\section{Chemical composition of insect species}

In a feasibility study, Veldkamp et al. (2012) concluded that the use of insects as a sustainable protein-rich feed ingredient in pig and poultry diets is possible based on their nutritional value but their maximum inclusion levels to replace traditional protein sources should be studied further. The amino acid profile of yellow mealworm (Tenebrio molitor; TM), common housefly (HF), and black soldier fly (BSF) is close to the profile of soybean meal (Veldkamp and Bosch, 2015). The chemical composition of the insect species included in the present review - BSF prepupae products, HF larval meal and mealworm larvae - and the traditional protein sources soybean meal and fishmeal is presented in Table 1 . The protein content of the insect species is comparable to soybean meal but lower than fishmeal and the fat content of the insect species is higher than in soybean meal and fishmeal. The amino acid profile of the insect species is close to the profile in soybean meal and fishmeal.

To compete with conventional protein sources for animal feeds and to become an interesting link in the animal feed chain to meet the growing global demand for protein, the cost price of insect production must be further reduced. However, insect production and related research are just in their infant stage. Literature on possible beneficial effects of insect products as feed ingredient on health of livestock animals is still scarce. Beneficial health effects of including insect products in pig diets may give applications in pig production an added value. Presence of chitin, lauric acid and antimicrobial peptides in insects as potential functional constituents may have positive health effects in monogastric animals (Dörper et al., 2021; Gasco et al., 2018; Jozefiak and Engberg, 2017).

\section{Digestibility of insect products and insect- based diets}

In total, five experiments were found with weaned piglets and two experiments with growing pigs. In five experiments different mealworm products were tested and in two experiments BSF products were tested. Most of the digestibility experiments are based on exchange of a traditional protein source by insect protein and so nutrient digestibility in these experiments has been evaluated at the level of the diet. Only in two papers the digestibility of the insect protein as such was evaluated. With respect to digestibility of diets as presented in Table 2 it should be noted that the nutrient digestibility of diets is affected by the nature of exchange of protein sources in the diet. Therefore, these values should be judged in this context.

\section{Weaned piglets}

Nutrient digestibility in weaned piglets was determined for 0, 1 and 2\% inclusion of dried Ptecticus tenebrifer (PT) larvae at the expense of fishmeal (Ao and Kim, 2019). The apparent total tract digestibility (ATTD) of DM (78.8 vs $81.9 \%$, respectively) and $\mathrm{N}$ (78.6 vs $81.6 \%$, respectively) was at $1 \% \mathrm{PT}$ inclusion lower than at the control diet at $56 \mathrm{~d}$ of age. Also Meyer et al. (2020) observed that ileal digestibility of all amino acids in weaned piglets at $63 \mathrm{~d}$ of age, except aspartic acid, were 6.7 to $15.6 \%$ lower at $10 \%$ TM inclusion than at 0\% TM inclusion. Contrary to Ao and Kim (2019) and Meyer et al. (2020), nitrogen retention and apparent total tract digestibility of DM and CP linearly increased when weaned piglets were fed diets with increasing inclusion levels of ground dried TM larvae (Jin et al., 2016). Digestibility of DM and CP increased from 90 to $94 \%$ and from 86 to $93 \%$, respectively at $0 \%$ and 6\% TM larvae inclusion (Jin et al., 2016). Nitrogen retention increased linearly from 2.2 to $2.4 \mathrm{~g} / \mathrm{d}$ at 0 and $6 \%$ TM larvae inclusion, respectively. It should be noted that 
Table 1. Chemical composition of black soldier fly prepupae products, housefly larval meal, mealworm larvae, soybean meal and fishmeal. $^{1}$

\begin{tabular}{|c|c|c|c|c|c|c|c|}
\hline & $\begin{array}{l}\text { BSF prepupae grown } \\
\text { on vegetable waste }\end{array}$ & $\begin{array}{l}\text { Full fat BSF larval } \\
\text { meal }\end{array}$ & $\begin{array}{l}\text { Partially defatted } \\
\text { BSF larval meal }\end{array}$ & $\begin{array}{l}\text { HF larval } \\
\text { meal }\end{array}$ & TM larvae & $\begin{array}{l}\text { Soybean } \\
\text { meal }\end{array}$ & Fishmeal \\
\hline \multicolumn{8}{|l|}{$\mathrm{g} / \mathrm{kg}$} \\
\hline Dry matter & 410 & 884 & 939 & 920 & 381 & 877 & 913 \\
\hline Crude ash & 96 & 74 & 68 & 65 & 24 & 64 & 168 \\
\hline Crude protein & 399 & 425 & 408 & 533 & 491 & 467 & 629 \\
\hline Crude fat & 371 & 325 & 128 & 203 & 352 & 15 & 98 \\
\hline $\mathrm{Ca}$ & 28.7 & 20.8 & 5.8 & - & 0.4 & 2.9 & 40.3 \\
\hline$P$ & 4.0 & 4.7 & 7.6 & - & 7.5 & 6.4 & 26.0 \\
\hline \multicolumn{8}{|l|}{$\mathrm{g} / 16 \mathrm{~g} \mathrm{~N}$} \\
\hline Lys & 5.7 & 6.2 & 6.2 & 7.1 & 5.5 & 6.2 & 7.6 \\
\hline Met & 1.9 & 2.5 & 2.9 & 2.5 & 1.3 & 1.4 & 2.8 \\
\hline Cys & 0.5 & 0.7 & 1.5 & 2.8 & 0.9 & 1.5 & 0.9 \\
\hline Thr & 3.9 & 4.2 & 4.0 & 5.3 & 5.1 & 3.9 & 4.2 \\
\hline Trp & 1.5 & - & - & 6.5 & 4.1 & 1.3 & 1.1 \\
\hline lle & 4.3 & 5.6 & 4.9 & 3.6 & 5.0 & 4.6 & 4.2 \\
\hline $\operatorname{Arg}$ & 5.0 & 5.7 & 5.2 & 4.8 & 5.2 & 7.5 & 5.9 \\
\hline Phe & 4.1 & 5.5 & 4.4 & 6.0 & 3.5 & 5.2 & 3.9 \\
\hline His & 3.1 & 3.7 & 3.0 & 2.9 & 3.2 & 2.7 & 2.6 \\
\hline Leu & 7.0 & 8.6 & 7.6 & 6.1 & 10.6 & 7.7 & 7.3 \\
\hline Tyr & - & - & - & 6.5 & 0.8 & 3.7 & 3.1 \\
\hline Val & 6.2 & 7.2 & 6.7 & 4.3 & 7.3 & 4.8 & 4.9 \\
\hline Ala & 6.1 & 7.3 & 8.2 & 5.5 & 8.2 & 4.4 & 6.3 \\
\hline Asp & 9.0 & 11.0 & 10.3 & 9.9 & 8.1 & 11.6 & 9.3 \\
\hline Glu & 10.4 & 11.6 & 15.3 & 13.4 & 11.3 & 17.8 & 13.0 \\
\hline Gly & 5.6 & 7.2 & 6.2 & 4.5 & 5.6 & 4.3 & 6.5 \\
\hline Pro & 5.4 & 7.2 & 7.8 & 3.8 & 7.0 & 5.1 & 4.4 \\
\hline Ser & 3.8 & 4.8 & 5.0 & 2.5 & 5.1 & 5.1 & 4.0 \\
\hline Sum_AA & 83.3 & 99.0 & 99.4 & 97.9 & 97.8 & 98.8 & 92.0 \\
\hline \multirow[t]{2}{*}{ Reference } & adapted from & adapted from & adapted from & adapted from & adapted from & CVB (2019) & CVB (2019) \\
\hline & Spranghers et al. (2017) & $\begin{array}{l}\text { Crosbie et al. } \\
(2020)\end{array}$ & $\begin{array}{l}\text { Crosbie et al. } \\
(2020)\end{array}$ & $\begin{array}{l}\text { Hall et al. } \\
(2018)\end{array}$ & Finke (2002) & & \\
\hline
\end{tabular}

this is only partly due to improved digestibility and more to the complete nutrient balance of the diets.

Biasato et al. (2019) concluded that ATTD was not affected in weaned piglets fed diets with 0,5 and $10 \%$ inclusion of partially defatted BSF larval meal at the expense of soybean meal at $23 \mathrm{~d}$ of age as well as at $61 \mathrm{~d}$ of age. Spranghers $e t$ al. (2018) evaluated ATTD and apparent ileal digestibility (AID) of full-fat BSF and defatted BSF in weaned piglets from 21 to $36 \mathrm{~d}$ of age. Full-fat BSF was included in the diet at 4 and $8 \%$ and defatted BSF was included in the diet at a level supplying a similar level of protein to the diet as the diet with defatted BSF at $8 \%$ and those treatments were compared with a control diet without BSF. Full-fat BSF or defatted BSF were included in the diet at the expense of toasted soybeans. ATTD of crude protein of the control diet did not differ significantly to that of the insect-containing feed (crude protein digestibility between 77 and $78 \%$ for all treatments). Whereas the AID of crude protein in the $8 \%$ full-fat BSF diet $(67.4 \%)$ was lower than that in the control diet (69.7\%), the crude protein digestibility for the $4 \%$ full-fat and the defatted BSF diets was higher (73.3\%) (Spranghers et al., 2018). 
Table 2. Nutrient digestibility of insect products and insect-based pig diets. ${ }^{1}$

\begin{tabular}{|c|c|c|c|c|c|c|}
\hline Pig species/type & Age (d) & Insect product & $\begin{array}{l}\text { Target } \\
\text { replacement }\end{array}$ & $\begin{array}{l}\text { Insect } \\
\text { inclusion \% }\end{array}$ & Results & Reference \\
\hline Weaned piglets & $21-36$ & $\begin{array}{l}\text { Full-fat BSF and } \\
\text { defatted BSF }\end{array}$ & Toasted soybeans & $0,4,8$ & $\begin{array}{l}\text { AID of CP in the } 8 \% \text { full- } \\
\text { fat BSF diet was lower } \\
\text { than that of the control } \\
\text { diet and AID of CP in } \\
\text { the } 4 \% \text { full-fat and the } \\
\text { defatted BSF diets was } \\
\text { higher. }\end{array}$ & $\begin{array}{l}\text { Spranghers et al. } \\
(2018)\end{array}$ \\
\hline $\begin{array}{l}\text { Weaned piglets ([Duroc× } \\
\text { Yorkshire]×Landrace) }\end{array}$ & $21-56$ & $\begin{array}{l}\text { Dried mealworm } \\
\text { (PT) powder }\end{array}$ & Fishmeal & $0,1,2$ & $\begin{array}{l}\text { ATTD of DM and } \mathrm{N} \text { at } \\
1 \% \text { inclusion was lower } \\
\text { than in the control diet. }\end{array}$ & Ao and $\operatorname{Kim}(2019)$ \\
\hline Weaned piglets (Topigs) & $21-61$ & $\begin{array}{l}\text { Partially defatted } \\
\text { BSF larval meal }\end{array}$ & Soybean meal & $0,5,10$ & $\begin{array}{l}\text { ATTD was not affected } \\
\text { by dietary treatment. }\end{array}$ & Biasato et al. (2019) \\
\hline $\begin{array}{l}\text { Weaned piglets ([Yorkshirex } \\
\text { Landrace]×Duroc) }\end{array}$ & $28-63$ & $\begin{array}{l}\text { Ground air-dried } \\
\text { TM larvae }\end{array}$ & $\begin{array}{l}\text { Soybean meal and } \\
\text { soy oil }\end{array}$ & $\begin{array}{l}0,1.5,3.0 \\
4.5,6.0\end{array}$ & $\begin{array}{l}\text { Nitrogen retention and } \\
\text { ATTD of DM and CP } \\
\text { linearly increased with } \\
\text { increasing TM levels. }\end{array}$ & Jin et al. (2016) \\
\hline $\begin{array}{l}\text { Weaned piglets (Piétrain× } \\
\text { [German Landrace×German } \\
\text { Edelschwein]) }\end{array}$ & $35-63$ & TM larvae & Soybean meal & $0,5,10$ & $\begin{array}{l}\text { AID of all AAs, except } \\
\text { aspartic acid, was lower } \\
\text { at } 10 \% \text { inclusion than at } \\
\text { the control diet. }\end{array}$ & Meyer et al. (2020) \\
\hline $\begin{array}{l}\text { Growing pigs ([Landracex } \\
\text { Yorkshire]×Duroc) }\end{array}$ & $24 \mathrm{~kg}$ & $\begin{array}{l}\text { Dried TM larvae } \\
\text { powder }\end{array}$ & $\begin{array}{l}\text { Fishmeal, meat } \\
\text { meal, poultry meal }\end{array}$ & 9.95 & $\begin{array}{l}\text { SID of DM, CP, total } \\
\text { AAs, essential AAs } \\
\text { and non-essential AAs } \\
\text { tended to be higher than } \\
\text { fishmeal, meat meal and } \\
\text { poultry meal. }\end{array}$ & Yoo et al. (2019) \\
\hline $\begin{array}{l}\text { Growing pigs ([Landracex } \\
\text { Yorkshire]×Duroc) }\end{array}$ & $29 \mathrm{~kg}$ & $\begin{array}{l}100 \% \text { defatted TM } \\
\text { larval meal and TM } \\
\text { larvae hydrolysate }\end{array}$ & Soybean meal & 0,10 & $\begin{array}{l}\text { AID of DM, CP, Lys, Met } \\
\text { and Thr in TM larvae } \\
\text { hydrolysate was higher } \\
\text { compared to fermented } \\
\text { poultry by-product and } \\
\text { hydrolysed fish soluble. }\end{array}$ & Cho et al. (2020) \\
\hline
\end{tabular}

\section{Growing pigs}

Yoo et al. (2019) determined standardised ileal digestibility (SID) of TM larvae powder, fishmeal, meat meal and poultry meal at an inclusion level of $9.95 \%$ in growing cannulated pigs of $24 \mathrm{~kg}$. The SID of Arg was higher $(P<0.05)$ in pigs fed TM diet compared to that in pigs fed fish meal or meat meal diets ( 90.0 vs 87.6 and $88.0 \%$, respectively). Furthermore, pigs fed poultry meal, meat meal, or TM diet showed increased $(P<0.05)$ SID of Cys compared to pigs fed fish meal diet $(88.4,86.6,90.2$ vs $83.6 \%$, respectively). Pigs fed the TM diet tended to show increased SID of DM, total energy, $\mathrm{CP}$, total amino acids (AAs), the other essential AAs (Lys, Met, Thr, Val, Ile, Leu, Phe and His), and the other non-essential AAs (Asp, Ser, Glu, Gly, Ala, Tyr and Pro) than pigs fed meat meal, poultry meal, or fish meal diet. In another study with growing pigs the AID of $100 \%$ defatted TM and TM larvae hydrolysate was determined in cannulated pigs of $29 \mathrm{~kg}$ (Cho et al., 2020). Pigs fed the hydrolysate of TM diet had higher SIDs of DM and CP (93.3\% and $93.2 \% ; P<0.05$, respectively) compared to pigs fed the other fermented poultry by-product and hydrolysed fish soluble diets. In the case of SIDs of total AAs although there was no difference between treatments $(P=0.06)$, pigs 
fed diets with hydrolysate of TM (83.4\%) showed higher digestibility, followed by those fed with fermented poultry by-product $(82.0 \%)$, defatted TM $(81.9 \%)$ and hydrolysed fish soluble diets (79.2\%). For SID of Lys, Met and Thr, pigs fed hydrolysate of TM and defatted TM larval meal diets showed higher SIDs $(P=0.05, P<0.05$ and $P<0.05$, respectively) than pigs fed fermented poultry by-product and hydrolysed fish soluble diets. SIDs of non-essential amino acids (Asp, Gly, Ala) were higher $(P<0.05, P<0.05$ and $P<0.05$, respectively) in pigs fed hydrolysate of TM, fermented poultry by-product, and defatted TM larval meal diets than those in pigs fed the hydrolysed fish soluble diet. AID and SID of Glu were higher in pigs fed hydrolysate of TM and fermented poultry by-product diets.

The two papers evaluating the SID of crude protein and amino acids in insect products are presented in Table 3 (Crosbie et al., 2020; Tan et al., 2020).

Crosbie et al. (2020) evaluated SID of amino acids and net energy contents in full fat and defatted BSF larval meals in growing pigs (Table 3). SID of CP (80.6\%) and Lys (88\%) were not different between full-fat BSF larval meal and partially defatted BSF larval meal. SID of the essential amino acids Arg (respectively 92.7 vs $95.9 \%$ ) and Val (respectively 83.2 vs $88.4 \%$ ) was lower and SID of Met (respectively 90.2 vs 79.3\%) was higher for full-fat BSF larval meal versus partially defatted BSF larval meal. In addition, the authors conclude that full-fat BSF larval meal was a better source of net energy for growing pigs than partially defatted BSF larval meal (3,479 vs $2,287 \mathrm{kcal} / \mathrm{kg}$ DM, respectively). Tan et al. (2020) determined the AID and the SID of amino acids in HF and BSF prepupae meal in growing pigs (25 kg). AID and SID of all essential amino acids in HF were higher than in BSF in growing pigs. Nutrient digestibility coefficients of defatted BSF larval meal and HF larval meal were in general comparable with digestibility coefficients of soybean meal and fishmeal except for Met which was in partially in BSF larval meal (79.3\%) lower than in soybean meal (90.0\%) and fishmeal (89.0\%). Nutrient digestibility of HF larval meal was higher than BSF larval meal.

In summary, digestibility of dietary nutrients showed variation in weaned piglets when soybean meal and fishmeal were replaced by TM and when soybean meal and toasted soybeans were replaced by BSF larval meal. In growing pigs, TM inclusion in the diet resulted in a higher nutrient digestibility compared to fishmeal, hydrolysed fish soluble, meat meal, poultry meal and fermented poultry byproduct based diets. The variability in nutrient digestibility of insect products in different studies is mainly due to changes in diet composition when insect products are included. The heterogeneity of the results in studies may also be attributed to the insect species, the insect life stage (adult, larva or pupa), the insect rearing substrate, and processing techniques and conditions (temperature at drying, extraction techniques, chitin removal) which all may influence the nutritive value of the insect products used (Barragan-Fonseca et al., 2017; Cho et al., 2020; Crosbie et al., 2020; Gasco et al., 2019; Sánchez-Muros et al., 2014). Two digestion experiments were conducted in which the only protein source was the insect protein source of consideration. From these two experiments with full-fat BSF larval meal, partially defatted BSF larval meal,

Table 3. Standardised ileal digestibility of crude protein and essential amino acids in black soldier fly prepupae products and housefly prepupae meal, soybean meal and fishmeal. ${ }^{1}$

\begin{tabular}{|c|c|c|c|c|c|c|}
\hline & $\begin{array}{l}\text { Full fat BSF larval } \\
\text { meal }\end{array}$ & $\begin{array}{l}\text { Partially defatted } \\
\text { BSF larval meal }\end{array}$ & BSF prepupae meal & HF prepupae meal & Soybean meal & $\begin{array}{l}\text { Fishmeal, } \\
\text { treated }\end{array}$ \\
\hline \multicolumn{7}{|l|}{$\%$} \\
\hline Crude protein & 80.2 & 81.0 & - & - & 87.0 & 85.0 \\
\hline Lys & 86.8 & 89.1 & 77.6 & 91.8 & 89.0 & 89.0 \\
\hline Met & 90.2 & 79.3 & 91.8 & 98.8 & 90.0 & 89.0 \\
\hline Thr & 87.2 & 86.6 & 79.8 & 91.9 & 85.0 & 88.0 \\
\hline lle & 87.2 & 89.6 & 77.5 & 87.8 & 88.0 & 90.0 \\
\hline $\operatorname{Arg}$ & 92.7 & 95.9 & 86.2 & 97.3 & 93.0 & 92.0 \\
\hline Phe & 95.4 & 97.6 & 76.7 & 90.6 & 89.0 & 87.0 \\
\hline His & 80.7 & 84.3 & 77.8 & 89.6 & 90.0 & 87.0 \\
\hline Leu & 87.2 & 90.7 & 81.0 & 91.8 & 87.0 & 90.0 \\
\hline Val & 83.2 & 88.4 & 80.9 & 91.0 & 87.0 & 89.0 \\
\hline Reference & Crosbie et al. (2020) & Crosbie et al. (2020) & Tan et al. (2020) & Tan et al. (2020) & CVB (2019) & CVB (2019) \\
\hline
\end{tabular}


and HF larval meal it can be concluded that amino acid digestibility of the evaluated insect products is comparable to the amino acid digestibility of soybean meal and fishmeal. HF larval meal amino acid digestibility was higher than in BSF larval meal.

\section{Growth performance}

In literature, one experiment was conducted with nursing piglets, six with weaned piglets, two with growing pigs and one with finishing pigs (Table 4). In three experiments different mealworm products were tested, six experiments with BSF products and one experiment with HF.

\section{Nursing piglets}

Driemeyer (2016) studied the effect of 3.5\% BSF larvae inclusion at the expense of fishmeal in pig creep diets on growth performance from 10 to 28 days of age. FI and body weight gain (BWG) were not affected by dietary treatment.

\section{Weaned piglets}

In an experiment of (Ao and Kim, 2019) body weight (BW) at $1 \% \mathrm{PT}$ inclusion was lower than at control diet at $56 \mathrm{~d}$ of age ( $21.0 \mathrm{vs} 21.8 \mathrm{~kg}$, respectively). Feed conversion ratio (FCR) at 1 and 2\% PT inclusion was higher from 21 to $28 \mathrm{~d}$ of age (1.24 and 1.23, respectively) than for the control diet (1.17). Inclusion of 5 or 10\% TM in diets for weaned

Table 4. Growth performance in pigs fed insect products. ${ }^{1}$

\begin{tabular}{|c|c|c|c|c|c|c|}
\hline Pig species/type & Age (d) & Insect product & $\begin{array}{l}\text { Target } \\
\text { replacement }\end{array}$ & $\begin{array}{l}\text { Insect } \\
\text { inclusion \% }\end{array}$ & Results & Reference \\
\hline $\begin{array}{l}\text { Nursing piglets (Large White } \\
\text { and Landrace) }\end{array}$ & $10-28$ & $\begin{array}{l}\text { Milled and sieved } \\
(3 \mathrm{~mm}) \text { BSF larvae }\end{array}$ & Fishmeal & $0,3.5$ & $\begin{array}{l}\text { Growth performance was not } \\
\text { affected. }\end{array}$ & $\begin{array}{l}\text { Driemeyer } \\
\text { (2016) }\end{array}$ \\
\hline Weaned piglets & $21-36$ & $\begin{array}{l}\text { Full-fat BSF and } \\
\text { defatted BSF }\end{array}$ & $\begin{array}{l}\text { Toasted } \\
\text { soybeans }\end{array}$ & $0,4,8$ & $\begin{array}{l}\text { Growth performance was not } \\
\text { affected. }\end{array}$ & $\begin{array}{l}\text { Spranghers } \\
\text { et al. (2018) }\end{array}$ \\
\hline $\begin{array}{l}\text { Weaned piglets ([Duroc× } \\
\text { Yorkshire]×Landrace) }\end{array}$ & $21-56$ & $\begin{array}{l}\text { Dried mealworm } \\
\text { (PT) powder }\end{array}$ & Fishmeal & $0,1,2$ & $\begin{array}{l}\text { Final BW at } 1 \% \text { inclusion was } \\
\text { lower than at control diet. FCR } \\
\text { at } 1 \text { and } 2 \% \text { inclusion was } \\
\text { higher than at control diet. BWG } \\
\text { at } 1 \% \text { inclusion was lower than } \\
\text { at control diet during } 29-42 \text { and } \\
21-56 \mathrm{~d} \text { of age. }\end{array}$ & $\begin{array}{l}\text { Ao and Kim } \\
(2019)\end{array}$ \\
\hline Weaned piglets (Topigs) & $21-61$ & $\begin{array}{l}\text { Partially defatted } \\
\text { BSF larva meal }\end{array}$ & Soybean meal & $0,5,10$ & $\begin{array}{l}\text { Fl in phase II increased linearly } \\
\text { with increasing inclusion levels. }\end{array}$ & $\begin{array}{l}\text { Biasato et al. } \\
(2019)\end{array}$ \\
\hline Weaned piglets & $21-61$ & BSF larvae oil & Corn oil & $0,2,4,6$ & $\begin{array}{l}\text { BW and BWG increased linearly } \\
\text { and FCR decreased linearly at } \\
\text { increasing inclusion levels. }\end{array}$ & $\begin{array}{l}\text { Van Heugten } \\
\text { et al. (2019) }\end{array}$ \\
\hline $\begin{array}{l}\text { Weaned piglets ([Yorkshirex } \\
\text { Landrace]×Duroc) }\end{array}$ & $28-63$ & $\begin{array}{l}\text { Ground air-dried } \\
\text { TM larvae }\end{array}$ & $\begin{array}{l}\text { Soybean meal } \\
\text { and soy oil }\end{array}$ & $\begin{array}{l}0,1.5,3.0 \\
4.5,6.0\end{array}$ & $\begin{array}{l}\mathrm{FI}, \mathrm{BW} \text { and BWG increased } \\
\text { linearly at increasing inclusion } \\
\text { levels during phase I (28-42 d). }\end{array}$ & Jin et al. (2016) \\
\hline $\begin{array}{l}\text { Weaned piglets (Piétrain× } \\
\text { [German Landrace×German } \\
\text { Edelschwein]) }\end{array}$ & $35-63$ & TM larvae & Soybean meal & $0,5,10$ & $\begin{array}{l}\text { BWG at } 10 \% \text { inclusion was lower } \\
\text { than at } 0 \% \text { and } 5 \% \text { inclusion. }\end{array}$ & $\begin{array}{l}\text { Meyer et al. } \\
(2020)\end{array}$ \\
\hline Growing pigs (Large White) & $11-29 \mathrm{~kg}$ & $\begin{array}{l}\text { Ground sun-dried } \\
\text { HF larvae }\end{array}$ & Fishmeal & 0,10 & $\begin{array}{l}\text { BWG was higher and FCR was } \\
\text { lower for HF larvae-fed pigs } \\
\text { compared to fishmeal-fed pigs. }\end{array}$ & $\begin{array}{l}\text { Dankwa et al. } \\
(2000)\end{array}$ \\
\hline $\begin{array}{l}\text { Growing pigs (Large Whitex } \\
\text { Landrace) }\end{array}$ & $18-53 \mathrm{~kg}$ & $\begin{array}{l}\text { Dried BSF larval } \\
\text { meal }\end{array}$ & Fishmeal & $\begin{array}{l}0,9,12 \\
14.5,18.5\end{array}$ & $\begin{array}{l}\text { Growth performance was not } \\
\text { affected. }\end{array}$ & $\begin{array}{l}\text { Chia et al. } \\
\text { (2019) }\end{array}$ \\
\hline $\begin{array}{l}\text { Finishing pigs ([Duroc× } \\
\text { Landrace]× Large White) }\end{array}$ & $76-115 \mathrm{~kg}$ & $\begin{array}{l}\text { Dried BSF larvae } \\
\text { powder }\end{array}$ & Soybean meal & $0,4,8$ & $\begin{array}{l}\text { BW and BWG at } 4 \% \text { inclusion } \\
\text { was higher and FCR was lower } \\
\text { than at } 0 \text { and } 8 \% \text { inclusion. }\end{array}$ & Yu et al. (2019) \\
\hline
\end{tabular}


piglets from 35 to $63 \mathrm{~d}$ of age did not affect performance parameters (FI, BW, FCR) (Meyer et al., 2020). Only daily BWG was lower in pigs fed diets with $10 \%$ TM compared to pigs fed control diets and 5\% inclusion level (573 vs 636 and $614 \mathrm{~g} / \mathrm{d}$, respectively). The authors stated, however, that the number of pigs in the study is rather limited and the number of observations is rather low for a classical performance trial. Jin et al. (2016) included dried TM (0, 1.5, 3.0, 4.5 and $6.0 \%$ ) at the expense of soybean meal and studied the effects on growth performance of weaned piglets. FI, BW and BWG improved linearly when the piglets were fed increasing levels of TM larvae in feeding phase I (28-42 d of age). BWG tended $(P=0.08)$ to increase linearly at increasing TM levels during phase II (42-63 d of age) and overall FCR tended $(P=0.07)$ to improve linearly at increasing TM levels up to the highest inclusion level of $6 \%$.

Biasato et al. (2019) reported that growth performance was not affected in weaned piglets fed a two-phase diet except for FI in phase II. A linear response of FI to increasing BSF meal levels (0, 5 and 10\% BSF larval meal) was observed (940, 950 and $970 \mathrm{~g} / \mathrm{d}$, respectively). Spranghers et al. (2018) studied also the effect on growth performance of weaned piglets fed diets with 4 and $8 \%$ full-fat BSF and $5.4 \%$ defatted BSF from 21 to $36 \mathrm{~d}$ of age. Defatted BSF was included in the diet at a level supplying a similar level of protein to the diet as the diet with defatted BSF at $8 \%$ and those treatments were compared with a control diet without BSF. BSF was included in the diet at the expense of toasted soybeans. Growth performance (FI, BWG and FCR) was not affected by dietary treatment.

\section{Growing pigs}

In growing pigs partial or full replacement of fishmeal in diets by BSF larval meal up to $18.5 \%$ BSF larvae inclusion at full replacement of fishmeal did not affect FI, BWG and FCR (Chia et al., 2019).

When $10 \%$ ground sun-dried HF larvae was included to replace $10 \%$ fishmeal in growing pig diets, CP content of the diets was almost similar and crude fat content in the diets with HF larvae was higher than in fishmeal diets (Dankwa et al., 2000). In the growth period from 11 to $29 \mathrm{~kg}$ daily BWG of pigs fed diets with 10\% HF larvae was higher (290 vs $250 \mathrm{~g} / \mathrm{d}$, respectively) and FCR was lower (3.29 vs 3.64, respectively) compared to pigs fed diets containing $10 \%$ fishmeal (Dankwa et al., 2000).

\section{Finishing pigs}

In finishing pigs (76-115 kg) inclusion of $4 \%$ dried BSF larvae powder at the expense of soybean meal resulted in a higher final BW (120 vs 116 and $115 \mathrm{~kg}$, respectively) and BWG ( 980 vs 890 and $860 \mathrm{~g} / \mathrm{d}$ ) and a lower FCR ( 2.85 vs 3.21 and 3.24, respectively) compared to 0 and $8 \%$ inclusion ( $\mathrm{Yu}$ et al., 2019). FI was not affected by dietary inclusion of BSF larvae powder. The authors suggested that the underlying mechanism may be associated with the up-regulated expression of genes related to the lipogenic potential and muscle fibre composition. The lack of positive effects in the finishing pigs fed diets with $8 \%$ BSF larvae may be due to the higher level of chitin in the BSF larvae diet.

Next to insects as dietary protein source one study evaluated the inclusion of insect oil in diets for weaned piglets. The impact of increasing levels of supplemental BSF larvae oil on growth performance was studied in weaned piglets from 21 to $61 \mathrm{~d}$ of age (Van Heugten et al., 2019). Treatments consisted of 0, 2, 4 and 6\% supplemental BSF larvae oil, replacing equal amounts of corn oil. Supplementation of BSF larvae oil linearly increased BW and BWG until $46 \mathrm{~d}$ of age and overall. FCR was improved linearly until $46 \mathrm{~d}$ of age, and FI was not affected.

In summary growth performance was not affected by BSF larvae inclusion in an experiment with nursing piglets. Effects of mealworm and BSF larvae inclusion in weaned piglets diets on growth performance results were not consistent. In an experiment with growing pigs dietary inclusion of BSF larvae replacing fishmeal did not affect growth performance and in an experiment with growing pigs dietary inclusion of HF larvae replacing fishmeal improved growth performance. In finishing pigs an inclusion of $4 \%$ BSF larvae replacing soybean meal resulted in an improved growth performance compared to 0 and $8 \%$ inclusion. Including BSF larvae oil replacing corn oil up to $6 \%$ improved growth performance linearly in weaned piglets. The effect of insect products on growth performance results is highly dependent on study design, formulation of the diets and the nutritional value of insects included in the feed formulation matrix. Some of the effects observed related to the dietary inclusion of insects products are likely also related to the previous points.

\section{Carcass and meat quality}

Two studies are included reporting the effects of dietary insect inclusion on carcass and meat quality. In one experiment product quality was observed in growing pigs and in one experiment in finishing pigs. One study was based on HF larvae and one study on BSF larvae.

\section{Growing pigs}

Dankwa et al. (2000) replaced 10\% fishmeal by ground sun-dried HF larvae in diets for growing pigs. Replacement did not affect dressing percentage and eye muscle area. Shoulder fat content in pigs fed sun-dried HF larvae was higher (3.02 vs $2.65 \mathrm{~cm}$, respectively) than fat content in growing pigs fed fishmeal. This can be the result of excess energy in the diet containing HF larvae. 


\section{Finishing pigs}

In finishing pigs (76-115 kg) dietary inclusion of dried BSF larvae powder at the expense of soybean meal affected carcass and meat quality (Yu et al., 2019). Inclusion of 4\% BSF larvae powder in the diet improved carcass traits and muscle chemical composition of finishing pigs and affected the meat quality via upregulating the expression of genes related to the lipogenic potential and muscle fibre composition in the longissimus thoracis of pigs. Loineye area (54.7 and $49.3 \mathrm{~cm}$ vs $45.4 \mathrm{~cm}$, respectively) was increased at 4 and $8 \%$ compared with the control treatment.

\section{Health}

Different health related parameters were measured in eight studies reported in literature with insect inclusion in the diet (Table 5). One experiment was conducted with nursing piglets, six with weaned piglets and one experiment with growing pigs. Two studies were conducted in which TM products were included and in six studies BSF products were included.

\section{Nursing piglets}

Driemeyer (2016) investigated the effect of BSF larval meal supplementation on nursing piglet blood parameters of 28 litters in two treatments (a control diet with $0 \%$ larval meal inclusion and a diet with 3.5\% inclusion of larval meal). Inclusion of $3.5 \%$ BSF larval meal in pig creep diets did not affect haematological and biochemical concentrations at 28 days of age. However, the author reported that the BSF larval meal diet showed an increased haemoglobin concentration and a higher haematocrit value. According to the author, these results may be considered as an indication of immunological stress, however, the animals did not show physical signs of distress when compared to the control group.

\section{Weaned piglets}

Meyer et al. (2020) concluded that TM meal can be used as a dietary source of protein in weaned pigs without causing adverse effects on intermediary metabolism. The highest TM meal inclusion level in this study was $10 \%$. Plasma metabolomics revealed higher concentrations of Ala, Asp, Glu, Pro, Ser, Tyr and Val and a lower concentration of Asn at $10 \%$ inclusion than at control diet. Only one out of fourteen quantifiable amino acid metabolites, namely methionine sulfoxide (MetS), in plasma was elevated by $45 \%$ and $71 \%$ at 5 and $10 \%$ inclusion, respectively, compared to control diet $(P<0.05)$. Plasma concentrations of both, major carnitine/ acylcarnitine species and bile acids were not different across groups. Lipidomics of liver and plasma demonstrated no differences in the concentrations of triacylglycerols, cholesterol and the main phospholipids, lysophospholipids and sphingolipids between groups. It was concluded that TM can be used as a dietary source of protein in pigs without causing adverse effects on metabolism of growing pigs. Jin et al. (2016) determined blood profiles in weaned piglets fed different TM inclusion levels. Blood urea nitrogen decreased linearly and insulinlike growth factor (IGF-1) increased linearly at increasing TM levels in phase II (42-63 d). High levels of blood urea nitrogen indicate that excessive amino acids are metabolised and circulate in the blood. IGF-1 as growth hormone plays an important role in controlling the structure, function of cardiovascular system and skeletal maturation (BayesGenis et al., 2000). Blood immunoglobulin A (IgA) and G concentrations were measured as indicators of the immune response but were not affected by inclusion of TM in diets for weaned piglets.

Biasato et al. (2019) studied haematological, biochemical, morphometric and histopathological parameters in weaned piglets fed 0,5 or $10 \%$ partially defatted BSF larvae at the expense of soybean meal. The parameters were not affected, except for the counts of monocytes and neutrophils, a linear and quadratic response was observed, respectively, to increasing BSF meal levels (with the maximum values corresponding to 10 and 5\% BSF inclusion, respectively). This finding is difficult to explain, since none of the BSF-fed piglets showed any signs of physical distress or inflammatory diseases. Spranghers et al. (2018) studied intestinal health parameters in weaned piglets at $36 \mathrm{~d}$ of age fed diets with full-fat BSF and defatted BSF. Full-fat BSF was included at 4 and $8 \%$ and defatted BSF at a level supplying a similar level of protein to the diet as the diet with defatted BSF at 8\%. pH, Lactobacilli and Streptococci in stomach, proximal small intestine and distal small intestine were not affected by dietary treatment despite higher measured lauric acid concentrations in the different segments at both inclusion levels of full-fat BSF. Alteration of intestinal specific bacterial populations and immune homeostasis in weaned piglets fed BSF larval meal as a fishmeal replacement was studied from 28 to $56 \mathrm{~d}$ of age (Yu et al., 2020). BSF larval meal was included at 1, 2 and $4 \%$ at the expense of fishmeal. Inclusion of $2 \%$ BSF larval meal (replacement for $50 \%$ of dietary fishmeal) affected specific ileal and caecal bacterial populations and metabolic profiles, as well as the expression of mucosal immune genes. Dietary inclusion of $2 \%$ BSF larval meal selectively increased the number of certain probiotic bacteria, and the concentration of lactate and short chain fatty acids in the ileal and caecal digesta. Additionally, it selectively decreased the number of $E$. coli and the concentration of metabolites involved in nitrogen metabolism (branched chain fatty acids, biogenic amines, and phenolic and indolic compounds). The ileum mucosal mRNA expression of TLR4-MyD88-NF- $\mathrm{B}$ signalling pathway and proinflammatory cytokine genes, and TNF- $\alpha$ protein concentration were decreased, but the mRNA expression of barrier function-, development- 
Table 5. Health of pigs fed insect products. ${ }^{1}$

\begin{tabular}{|c|c|c|c|c|c|c|}
\hline Pig species/type & Age (d) & Insect product & $\begin{array}{l}\text { Target } \\
\text { replacement }\end{array}$ & $\begin{array}{l}\text { Insect } \\
\text { inclusion \% }\end{array}$ & Results & Reference \\
\hline $\begin{array}{l}\text { Nursing piglets (Large White } \\
\text { and Landrace) }\end{array}$ & $10-28$ & $\begin{array}{l}\text { Milled and sieved } \\
(3 \mathrm{~mm}) \text { BSF larvae }\end{array}$ & Fishmeal & $0,3.5$ & $\begin{array}{l}\text { Evaluated haematological and } \\
\text { biochemical parameters were } \\
\text { not affected. }\end{array}$ & $\begin{array}{l}\text { Driemeyer } \\
(2016)\end{array}$ \\
\hline Weaned piglets & $21-36$ & $\begin{array}{l}\text { Full-fat BSF and } \\
\text { defatted BSF }\end{array}$ & $\begin{array}{l}\text { Toasted } \\
\text { soybeans }\end{array}$ & $0,4,8$ & $\begin{array}{l}\text { pH, Lactobacilli and D-Streptococci in } \\
\text { stomach, proximal small intestine and } \\
\text { distal small intestine were not affected. }\end{array}$ & $\begin{array}{l}\text { Spranghers } \\
\text { et al. (2018) }\end{array}$ \\
\hline Weaned piglets (Topigs) & $21-61$ & $\begin{array}{l}\text { Partially defatted } \\
\text { BSF larva meal }\end{array}$ & Soybean meal & $0,5,10$ & $\begin{array}{l}\text { Evaluated haematological and } \\
\text { biochemical parameters were not } \\
\text { affected, except for the monocytes } \\
\text { and neutrophils, linear and quadratic } \\
\text { responses were observed. Gut } \\
\text { morphology and histological features } \\
\text { were not affected. }\end{array}$ & $\begin{array}{l}\text { Biasato et } \\
\text { al. (2019) }\end{array}$ \\
\hline Weaned piglets & $21-61$ & BSF larvae oil & Corn oil & $0,2,4,6$ & $\begin{array}{l}\text { Evaluated biochemical parameters } \\
\text { were not affected, except cholesterol } \\
\text { that increased linearly at higher } \\
\text { inclusion levels. Haematological } \\
\text { parameters were not affected, but } \\
\text { platelet count tended to linearly } \\
\text { increase at higher inclusion levels. }\end{array}$ & $\begin{array}{l}\text { Van Heugten } \\
\text { et al. (2019) }\end{array}$ \\
\hline $\begin{array}{l}\text { Weaned piglets ([Duroc } \times \\
\text { Landrace] } \times \text { Large White) }\end{array}$ & $28-56$ & $\begin{array}{l}\text { Full-fat BSF larval } \\
\text { meal }\end{array}$ & Fishmeal & $0,1,2,4$ & $\begin{array}{l}\text { Supplementation with } 2 \% \text { BSF larval } \\
\text { meal affected specific ileal and caecal } \\
\text { bacterial populations and metabolic } \\
\text { profiles, as well as the mucosal immune } \\
\text { genes expression. }\end{array}$ & $\begin{array}{l}\text { Yu et al. } \\
(2020)\end{array}$ \\
\hline $\begin{array}{l}\text { Weaned piglets } \\
\text { ([Yorkshire×Landrace]×Duroc) }\end{array}$ & $28-63$ & $\begin{array}{l}\text { Ground air-dried } \\
\text { TM larvae }\end{array}$ & $\begin{array}{l}\text { Soybean meal } \\
\text { and soy oil }\end{array}$ & $\begin{array}{l}0,1.5,3.0 \\
4.5,6.0\end{array}$ & $\begin{array}{l}\text { Blood urea nitrogen decreased linearly } \\
\text { and insulin-like growth factor increased } \\
\text { linearly at increasing inclusion levels in } \\
\text { phase II ( } 42-63 \mathrm{~d} \text { ). Immunoglobulin A } \\
\text { and G concentrations were not affected. }\end{array}$ & $\begin{array}{l}\text { Jin et al. } \\
(2016)\end{array}$ \\
\hline $\begin{array}{l}\text { Weaned piglets (Piétrain } \times \\
\text { [German Landrace } \times \text { German } \\
\text { Edelschwein]) }\end{array}$ & $35-63$ & TM larvae & Soybean meal & $0,5,10$ & $\begin{array}{l}\text { Higher blood plasma concentrations } \\
\text { of Ala, Asp, Glu, Pro, Ser, Tyr and Val } \\
\text { and a lower concentration of Asn at } \\
10 \% \text { inclusion than at control diet. } \\
\text { Plasma methionine sulfoxide was higher } \\
\text { at } 5 \% \text { and } 10 \% \text { inclusion, compared to } \\
\text { control diet. }\end{array}$ & $\begin{array}{l}\text { Meyer et al. } \\
(2020)\end{array}$ \\
\hline $\begin{array}{l}\text { Growing pigs (Large White } \times \\
\text { Landrace) }\end{array}$ & $\begin{array}{l}18-53 \\
\mathrm{~kg}\end{array}$ & $\begin{array}{l}\text { Dried BSF larval } \\
\text { meal }\end{array}$ & Fishmeal & $\begin{array}{l}0,9,12 \\
14.5,18.5\end{array}$ & $\begin{array}{l}\text { Red or white blood cell parameters } \\
\text { were not affected, except for neutrophil } \\
\text { counts, which were higher at } 14.5 \text { and } \\
18.5 \% \text { inclusion compared to control } \\
\text { diet. Platelet counts at } 9,14.5 \text { and } 18.5 \% \\
\text { inclusion were lower compared to control } \\
\text { diet and } 12 \% \text { inclusion. Blood cholesterol } \\
\text { levels were not affected. }\end{array}$ & $\begin{array}{l}\text { Chia et al. } \\
(2019)\end{array}$ \\
\hline
\end{tabular}

\footnotetext{
${ }^{1} \mathrm{Ala}=$ alanine; Asn = asparagine; Asp = aspartate; $\mathrm{Glu}=$ glutamate; Pro = proline; Ser = serine; Tyr = tyrosine; Val = valine; BSF = black soldier fly (Hermetia illucens); Ig = immunoglobulin; TM = mealworm (Tenebrio molitor).
} 
relative, and anti-inflammatory cytokines and sIgA protein concentrations were increased.

\section{Growing pigs}

Chia et al. (2019) studied blood parameters in growing pigs fed different inclusion levels of BSF larvae as blood profiles can provide an indication of the clinical health status as well as the extent to which dietary deficiencies impact the physiological status of the animal. Red or white blood cell concentrations were not affected at any inclusion level of BSF larval meal in diets for growing pigs (Chia et al., 2019) up to inclusion level of $18.5 \%$ at full replacement of fishmeal in the diet. Neutrophil counts were higher at 14.5 and $18.5 \%$ inclusion compared to control. Neutrophils are one of the first responders of inflammatory cells to migrate toward the site of inflammation. Platelet counts at 9, 14.5 and $18.5 \%$ inclusion were lower compared to 0 and $12 \%$ inclusion. Low platelet concentration implies that blood clotting might be impaired, resulting in blood loss in case of injury (Etim et al., 2014).

Van Heugten et al. (2019) studied the impact of increasing levels of supplemental BSF larval oil on serological and haematological indices in weaned piglets from 21 to $61 \mathrm{~d}$ of age. Treatments consisted of 0, 2, 4 and 6\% supplemental BSF larval oil, replacing equal amounts of corn oil. Supplemental BSF larval oil did not affect serological parameters, but linearly increased serum cholesterol. Haematological parameters were also not affected by BSF larval oil, but platelet count tended $(P=0.082)$ to linearly increase at increased BSF larval oil inclusion levels.

Overall it can be summarised that health related haematological, biochemical and intestinal health parameters were not affected by dietary inclusion of insect products. Only in one study inclusion of $2 \%$ BSF larval meal (replacement $50 \%$ of dietary fishmeal) affected specific ileal and caecal bacterial populations and metabolic profiles, as well as the ileal immune status in weaned piglets.

\section{Conclusions}

Amino acid digestibility of full-fat BSF larval meal, partially defatted BSF larval meal and HF larval meal were comparable to the amino acid digestibility of soybean meal and fishmeal and HF larval meal amino acid digestibility was higher than in BSF larval meal. Nutrient digestibility of insect-based diets showed variation within and between studies in weaned piglets and growing pigs. The variability in nutrient digestibility of insect products is mainly due to changes in diet composition when insect products are included. The nutrient digestibility of diets depends on the source of protein that is used or exchanged. Also differences in insect sources used and processing techniques applied may have affected nutrient digestibility in diets. Effects of different insect-based diets on growth performance results were also variable. The effect of insect products on growth performance results is highly dependent on study design, formulation of the diet and the nutritional value of insects adopted during feed formulation. For further studies it is recommended to distinguish studies aimed at determining nutritional value (digestibility studies) and growth performance studies in which the effects of the insect products as dietary ingredient are observed. Health related haematological and biochemical parameters were not affected by dietary inclusion of insect products. In general it can be stated that differences in results between studies may be related to differences in the nature of the insect species, the used substrate to grow the insects and life stages used, in dietary inclusion levels, in the way of processing of the insect products, to variation in palatability of diets, age of the animal and research methods applied. Overall it can be concluded that insect products seem to be a good alternative to partly replace soybean meal or fishmeal in piglet and pig diets without adversely affecting growth performance, product quality and health status. More standardised digestibility and growth performance experiments are recommended for future research and potential positive effects of the use of insect based ingredients on animal health deserve more attention.

\section{Acknowledgement}

We thank M. Dicke, A.J.M. Jansman and A. Dörper for constructive comments on a previous version of the manuscript.

\section{Conflict of interest}

The authors declare no conflict of interest.

\section{References}

Alltech, 2020. 2020 global feed survey. Alltech, Nicholasville, KY, USA. Anonymous, 2017. Factsheet varkenshouderij - feiten en cijfers over de Nederlandse varkenshouderij. POV, Zwolle, the Netherlands.

Ao, X. and Kim, I.H., 2019. Effects of dietary dried mealworm (Ptecticus tenebrifer) larvae on growth performance and nutrient digestibility in weaning pigs. Livestock Science 230: 4.

Bai, Z., Ma, W., Ma, L., Velthof, G.L., Wei, Z., Havlík, P., Oenema, O., Lee, M.R.F. and Zhang, F., 2018. China's livestock transition: driving forces, impacts, and consequences. Science Advances 4: 1-11. Barragan-Fonseca, K.B., Dicke, M. and Van Loon, J.J.A., 2017. Nutritional value of the black soldier fly (Hermetia illucens L.) and its suitability as animal feed - a review. Journal of Insects as Food and Feed 3: 105-120. https://doi.org/10.3920/JIFF2016.0055

Bayes-Genis, A., Conover, C.A. and Schwartz, R.S., 2000. The insulinlike growth factor axis: a review of atherosclerosis and restenosis. Circulation Research 86: 125-130. 
Biasato, I., Renna, M., Gai, F., Dabbou, S., Meneguz, M., Perona, G., Martinez, S., Lajusticia, A.C.B., Bergagna, S., Sardi, L., Capucchio, M.T., Bressan, E., Dama, A., Schiavone, A. and Gasco, L., 2019. Partially defatted black soldier fly larva meal inclusion in piglet diets: effects on the growth performance, nutrient digestibility, blood profile, gut morphology and histological features. Journal of Animal Science and Biotechnology 10: 11.

Chia, S.Y., Tanga, C.M., Osuga, I.M., Alaru, A.O., Mwangi, D.M., Githinji, M., Subramanian, S., Fiaboe, K.K.M., Ekesi, S., Van Loon, J.J.A. and Dicke, M., 2019. Effect of dietary replacement of fishmeal by insect meal on growth performance, blood profiles and economics of growing pigs in Kenya. Animals 9: 19.

Cho, K.H., Kang, S.W., Yoo, J.S., Song, D.K., Chung, Y.H., Kwon, G.T. and Kim, Y.Y., 2020. Effects of mealworm (Tenebrio molitor) larvae hydrolysate on nutrient ileal digestibility in growing pigs compared to those of defatted mealworm larvae meal, fermented poultry byproduct, and hydrolyzed fish soluble. Asian-Australasian Journal of Animal Sciences 33: 490-500.

Crosbie, M., Zhu, C., Shoveller, A.K. and Huber, L.-A., 2020. Standardized ileal digestible amino acids and net energy contents in full fat and defatted black soldier fly larvae meals (Hermetia illucens) fed to growing pigs. Translational Animal Science 4: txaa104.

CVB, 2019. CVB veevoedertabel 2019 - chemische samenstellingen en nutritionele waarden van voedermiddelen. CVB, Wageningen, the Netherlands.

Dankwa, D., Oddoye, E. and Mzamo, K., 2000. Preliminary studies on the complete replacement of fishmeal by house-fly-larvae-meal in weaner pig diets: effects on growth rate, carcass characteristics, and some blood constituents. Ghana Journal of Agricultural Science 33: 223-227.

De Boer, J., Helms, M. and Aiking, H., 2006. Protein consumption and sustainability: diet diversity in EU-15. Ecological Economics 59: 267-274.

De Smet, S. and Vossen, E., 2016. Meat: the balance between nutrition and health. A review. Meat Science 120: 145-156.

De Visser, C.L.M., Schreuder, R. and Stoddard, F., 2014. The EU's dependency on soya bean import for the animal feed industry and potential for EU produced alternatives. OCL 21: D407.

Dörper, A., Veldkamp, T. and Dicke, M., 2021. Use of black soldier fly and house fly in feed to promote sustainable poultry production Journal of Insects as Food and Feed 7: 761-780, https://doi. org/10.3920/JIFF2020.0064.

Driemeyer, H., 2016. Evaluation of black soldier fly (Hermetia illucens) larvae as an alternative protein source in pig creep diets in relation to production, blood and manure microbiology parameters. MScthesis, Stellenbosch University, Stellenbosch, South Africa, 99 pp.

European Research Area on Sustainable Animal Production Systems (ERANET), 2020. SusAn. Available at: https://cordis.europa.eu/ project/id/696231

Etim, N.N., Offiong, E.E.A., Williams, M.E. and Asuquo, L.E., 2014. Influence of nutrition on blood parameters of pigs. American Journal of Biology and Life Sciences 2: 7.

Finke, M.D., 2002. Complete nutrient composition of commercially raised invertebrates used as food for insectivores. Zoo Biology 21: 269-285.
Florou-Paneri, P., Christaki, E., Giannenas, I., Bonos, E., Skoufos, I., Tsinas, A., Tzora, A. and Peng, J., 2014. Alternative protein sources to soybean meal in pig diets. Journal of Food Agriculture and Environment 12: 655-660.

Gasco, L., Biasato, I., Dabbou, S., Schiavone, A. and Gai, F., 2019. Animals fed insect-based diets: state-of-the-art on digestibility, performance and product quality. Animals 9: 32.

Gasco, L., Finke, M. and Van Huis, A., 2018. Can diets containing insects promote animal health? Journal of Insects as Food and Feed 4: 1-4. https://doi.org/10.3920/JIFF2018.x001

Hall, H.N., Masey O’Neill, H.V., Scholey, D., Burton, E., Dickinson, M. and Fitches, E.C., 2018. Amino acid digestibility of larval meal (Musca domestica) for broiler chickens. Poultry Science 97: 8.

Jin, X.H., Heo, P.S., Hong, J.S., Kim, N.J. and Kim, Y.Y., 2016. Supplementation of dried mealworm (Tenebrio molitor larva) on growth performance, nutrient digestibility and blood profiles in weaning pigs. Asian-Australasian Journal of Animal Sciences 29: 979-986

Jozefiak, A. and Engberg, R., 2017. Insect proteins as a potential source of antimicrobial peptides in livestock production. A review. Journal of Animal and Feed Sciences 26: 13.

Lassaletta, L., Billen, G., Romero, E., Garnier, J. and Aguilera, E., 2014. How changes in diet and trade patterns have shaped the $\mathrm{N}$ cycle at the national scale: Spain (1961-2009). Regional Environmental Change 14: 785-797.

Lassaletta, L., Estellés, F., Beusen, A.H.W., Bouwman, L., Calvet, S., Van Grinsven, H.J.M., Doelman, J.C., Stehfest, E., Uwizeye, A. and Westhoek, H., 2019. Future global pig production systems according to the shared socioeconomic pathways. Science of the Total Environment 665: 739-751.

Meyer, S., Gessner, D.K., Braune, M.S., Friedhoff, T., Most, E., Höring, M., Liebisch, G., Zorn, H., Eder, K. and Ringseis, R., 2020. Comprehensive evaluation of the metabolic effects of insect meal from Tenebrio molitor $L$. in growing pigs by transcriptomics, metabolomics and lipidomics. Journal of Animal Science and Biotechnology 11: 20.

Mottet, A., De Haan, C., Falcucci, A., Tempio, G., Opio, C. and Gerber, P., 2017. Livestock: on our plates or eating at our table? A new analysis of the feed/food debate. Global Food Security 14: 1-8.

Rauw, W.M., Rydhmer, L., Kyriazakis, I., Overland, M., Gilbert, H., Dekkers, J.C.M., Hermesch, S., Bouquet, A., Izquierdo, E.G., Louveau, I. and Gomez-Raya, L., 2020. Prospects for sustainability of pig production in relation to climate change and novel feed resources. Journal of the Science of Food and Agriculture 100: 3575-3586. https://doi.org/10.1002/jsfa.10338

Sánchez-Muros, M.-J., Barroso, F.G. and Manzano-Agugliaro, F., 2014. Insect meal as renewable source of food for animal feeding: a review. Journal of Cleaner Production 65: 16-27.

Soare, E. and Chiurciu, I.-A., 2017. Study on the pork market worldwide. Scientific Papers: Management, Economic Engineering in Agriculture \& Rural Development 17: 321-326.

Spranghers, T., Michiels, J., Vrancx, J., Ovyn, A., Eeckhout, M., De Clercq, P. and De Smet, S., 2018. Gut antimicrobial effects and nutritional value of black soldier fly (Herrnetia illucens $L$.) prepupae for weaned piglets. Animal Feed Science and Technology 235: 10. 
Spranghers, T., Ottoboni, M., Klootwijk, C., Ovyn, A., Deboosere, S., Meulenaer, B., Michiels, J., Eeckhout, M., De Clercq, P. and De Smet, S., 2017. Nutritional composition of black soldier fly (Hermetia illucens) prepupae reared on different organic waste substrates. Journal of the Science of Food and Agriculture 97: 2594-2600.

Steinfeld, H., Gerber, P., Wassenaar, T., Castel, V., Rosales, M., Rosales, M. and De Haan, C., 2006. Livestock's long shadow: environmental issues and options. FAO, Rome, Italy.

Tan, X., Yang, H.S., Wang, M., Yi, Z.F., Ji, F.J., Li, J.Z. and Yin, Y.L., 2020. Amino acid digestibility in housefly and black soldier fly prepupae by growing pigs. Animal Feed Science and Technology 263: 114446.

United Nations (UN), 2015. Resolution adopted by the General Assembly on 25 September 2015: 70/1. Transforming our world: the 2030 agenda for sustainable development. UN, New York, NY, USA.

United States Department of Agriculture (USDA), 2020. Livestock and poultry: world markets and trade. USDA, Washington, DC, USA.

Van Heugten, E., Martinez, G., McComb, A. and Koutsos, E., 2019. Black soldier fly (Hermetia illucens) larvae oil improves growth performance of nursery pigs. Journal of Animal Science 97: 1.

Van Huis, A. and Oonincx, D.G.A.B., 2017. The environmental sustainability of insects as food and feed. A review. Agronomy for Sustainable Development 37: 14. https://doi.org/10.1007/s13593017-0452-8

Van Zanten, H.H.E., Bikker, P., Meerburg, B.G. and De Boer, I.J.M., 2018. Attributional versus consequential life cycle assessment and feed optimization: alternative protein sources in pig diets. International Journal of Life Cycle Assessment 23: 1-11.
Veldkamp, T. and Bosch, G., 2015. Insects: a protein-rich feed ingredient in pig and poultry diets. Animal Frontiers 5: 45-50.

Veldkamp, T., Van Duinkerken, G., Van Huis, A., Lakemond, C.M.M., Ottevanger, E., Bosch, G. and Van Boekel, T., 2012. Insects as a sustainable feed ingredient in pig and poultry diets: a feasibility study. Wageningen UR Livestock Research, Lelystad, the Netherlands.

Wiedemann, S., McGahan, E. and Murphy, C., 2016. Environmental impacts and resource use from Australian pork production assessed using life-cycle assessment. Greenhouse gas emissions. Animal Production Science 56: 14.

Yoo, J.S., Cho, K.H., Hong, J.S., Jang, H.S., Chung, Y.H., Kwon, G.T., Shin, D.G. and Kim, Y.Y., 2019. Nutrient ileal digestibility evaluation of dried mealworm (Tenebrio molitor) larvae compared to three animal protein by-products in growing pigs. Asian-Australasian Journal of Animal Sciences 32: 387-394.

Yu, M., Li, Z., Chen, W., Wang, G., Rong, T., Liu, Z., Wang, F. and Ma, X., 2020. Hermetia illucens larvae as a fishmeal replacement alters intestinal specific bacterial populations and immune homeostasis in weanling piglets. Journal of Animal Science 98: 13.

Yu, M., Li, Z.M., Chen, W.D., Rong, T., Wang, G., Li, J.H. and Ma, X.Y., 2019. Use of Hermetia illucens larvae as a dietary protein source: effects on growth performance, carcass traits, and meat quality in finishing pigs. Meat Science 158: 7. 
